\title{
Infectieziektebestrijding 2.0: nieuwe wegen, nieuwe kansen!
}

Citation for published version (APA):

Hoebe, C. J. P. A. (2012). Infectieziektebestrijding 2.0: nieuwe wegen, nieuwe kansen! Maastricht University. https://doi.org/10.26481/spe.20121207ch

Document status and date:

Published: 07/12/2012

DOI:

$10.26481 / \mathrm{spe} .20121207 \mathrm{ch}$

Document Version:

Publisher's PDF, also known as Version of record

\section{Please check the document version of this publication:}

- A submitted manuscript is the version of the article upon submission and before peer-review. There can be important differences between the submitted version and the official published version of record.

People interested in the research are advised to contact the author for the final version of the publication, or visit the DOI to the publisher's website.

- The final author version and the galley proof are versions of the publication after peer review.

- The final published version features the final layout of the paper including the volume, issue and page numbers.

Link to publication

\footnotetext{
General rights rights.

- You may freely distribute the URL identifying the publication in the public portal. please follow below link for the End User Agreement:

www.umlib.nl/taverne-license

Take down policy

If you believe that this document breaches copyright please contact us at:

repository@maastrichtuniversity.nl

providing details and we will investigate your claim.
}

Copyright and moral rights for the publications made accessible in the public portal are retained by the authors and/or other copyright owners and it is a condition of accessing publications that users recognise and abide by the legal requirements associated with these

- Users may download and print one copy of any publication from the public portal for the purpose of private study or research.

- You may not further distribute the material or use it for any profit-making activity or commercial gain

If the publication is distributed under the terms of Article $25 \mathrm{fa}$ of the Dutch Copyright Act, indicated by the "Taverne" license above, 
Prof. dr. Christian J PA Hoebe

Faculty of Health, Medicine and Life Sciences

I nfectieziektebestrijding

2.0: nieuwe wegen, nieuwe kansen! 
Oratie uitgesproken 7 december 2012 door Prof.dr. Christian JPA Hoebe, Maastricht University, Faculty of Health, Medicine and Life Sciences, Maastricht ter aanvaarding van zijn bijzonderhoogleraarschap 'Infectious Disease Control'.

\section{Infectieziektebestrijding 2.0: nieuwe wegen, nieuwe kansen!}

Mijnheer de Rector, Zeer gewaardeerde collega's,

Beste familie, vrienden en overige toehoorders,

Ik wil mijn oratie beginnen met deze steen. Deze steen komt uit het bergachtige gebied van het plaatsje Barberton in Zuid-Afrika - dat ligt tussen Johannesburg en het Krugerpark. Ogenschijnlijk is deze steen niet erg bijzonder. Toch onthullen de stenen van Barberton de geheimen van de oorsprong van het leven.

Deze steen is namelijk maarliefst 3,5 miljard jaar oud en daarmee een van de oudste gesteenten ter wereld. Barberton is één van de weinige plekken op aarde waar geologische zulk oud gesteente aan de oppervlakte van de aardkorst voorkomt. Deze

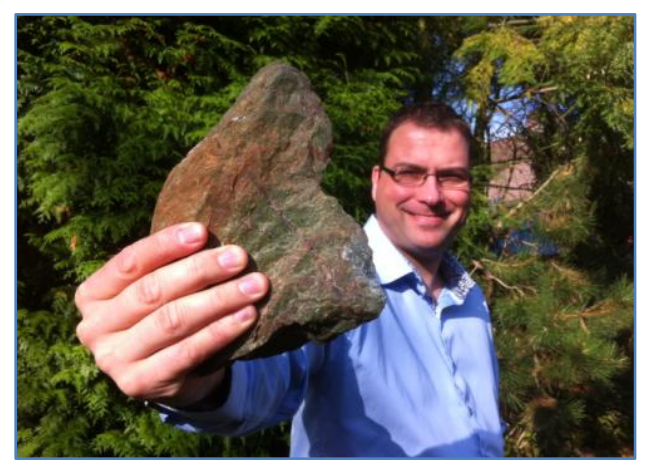
steen was erbij toen de continenten zich net begonnen te vormen. Het bijzondere is dat deze steen een van de eerste levensvormen op aarde bevat: bacterieachtige organismen. Op deze foto zie je een elektronenmicroscopische opname van een splinter van een vergelijkbare steen. ${ }^{1}$ In de rode cirkel zien we ronde bacteriën van 1 micron die net betrapt zijn tijdens het delen voordat ze blijkbaar onmiddellijk werden ingevroren en zo

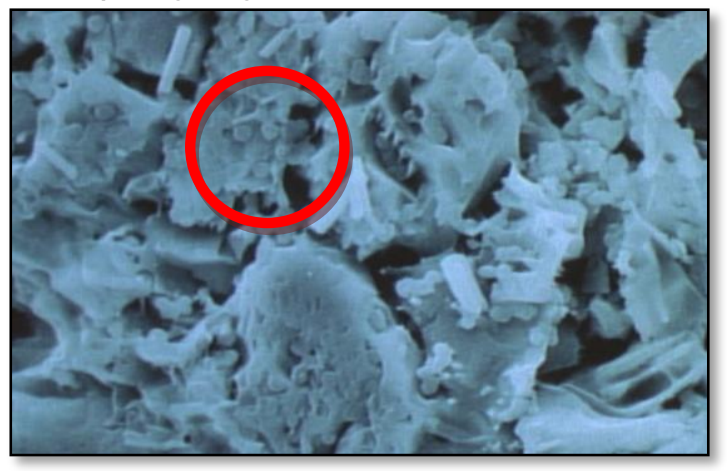
bewaard zijn gebleven. Dit zou dus wel eens om het oudste fossiel ter wereld kunnen gaan. 3,5 miljard jaar: zo lang zijn bacteriën dus al op aarde terwijl de mens 'pas' zo'n 200.000 jaar geleden op het aardse toneel verschijnt. Een extra reden om ontzag te hebben voor deze kleine aardbewoners.

Ik zal in mijn oratie eerst ingaan op infectieziekten en de rol die ze spelen. Dan geef ik drie infectieziekte-uitdagingen voor Nederland anno 2012 en ga ik in op de structuur van de infectieziektebestrijding. Ik vervolg met 3 antwoorden op de vraag: Wat kan beter in de infectieziektebestrijding? Ik zal die 3 antwoorden verbinden met een nieuwe visie op 
wetenschappelijk onderzoek binnen de infectieziektebestrijding. Daarna zal ik met een voorbeeld uit de praktijk deze visie verder inkleuren en tegelijkertijd illustreren met welk onderzoek ik door mijn leerstoel wil bijdragen.

\section{Infectieziekten}

Er zijn miljoenen micro-organismen ontstaan en de meesten daarvan zijn onschadelijk voor de mens en soms zelfs zeer nuttig. Maar er zijn er natuurlijk ook waarvan we wel ziek kunnen worden. Infectieziekten worden naast bacteriën, ook veroorzaakt door virussen, schimmels, parasieten, wormen en prionen. Ook de mens heeft dagelijks te maken met micro-organismen. Jullie allen hebben ongeveer 10 biljoen cellen in je lichaam - een biljoen heeft 12 nullen. Het aantal bacteriën in je lichaam is zelfs een factor 10 groter, dus 100 biljoen. Omdat bacteriën lichter zijn dan menselijke cellen is het ruim één kilo van je lichaamsgewicht. Dan hebben we het over de 'dierentuin' die jullie allen bij je draagt. Deze dierentuin noemen we ook wel het menselijk mircrobiome. Dit mircobiome is enorm belangrijk voor je gezondheid. Die ene kilo doet goed werk op allerlei plaatsen in je lichaam zoals aan vertering of bescherming tegen schadelijke micro-organismen op je huid. ${ }^{2}$ Zoals op deze dia te zien is heeft alleen je huid al verschillende eco-systemen met daardoor verschillende bacteriën. Iedere kleur stelt een ander beestje voor en er is te zien dat elke plek op het lichaam een andere samenstelling kent.

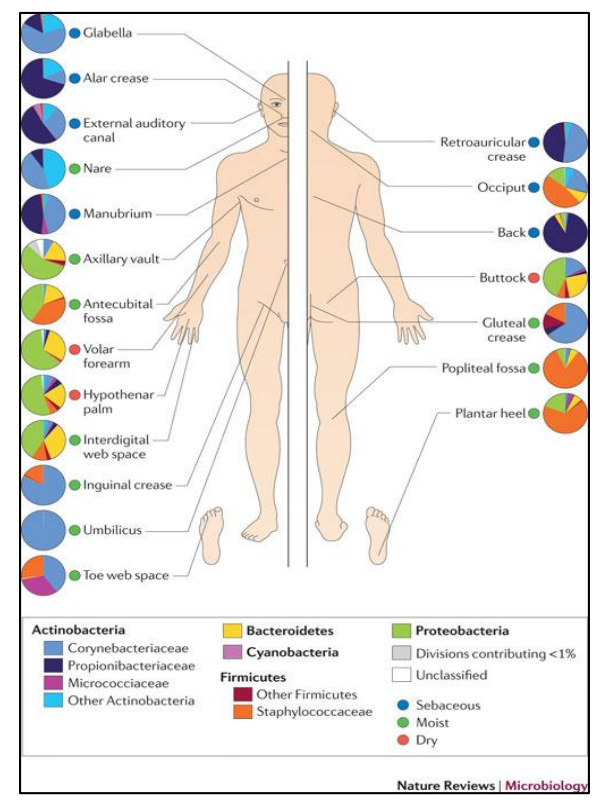

Men schat dat er 'slechts' 1400 micro-organismen ziekmakend zijn voor de mens. Naar schatting komt $60 \%$ van deze infectieziekten van dieren. Infectieziekten die overgedragen kunnen worden van dieren op mensen noemen we zoönosen. Dieren zijn dus een belangrijke bron van veel ziekmakende micro-organismen. ${ }^{3-5}$ Deze microorganismen zorgen al eeuwen voor een uitdaging voor de volksgezondheid. Microorganismen hebben zelfs vaak onze geschiedenis bepaald met dodelijke gevolgen voor duizenden mensen zoals met de mazelen en pokken introductie door de eerste ontdekkingsreizigers onder de indianen, en pest epidemieën in de Middeleeuwen of met een influenza shift bij de Spaanse griep epidemie eind 1918. Na de ontdekking en wereldwijde toepassing van antibiotica na de Tweede Wereldoorlog en de uitroeiing van het pokkenvirus in de jaren '70 door een effectief pokken vaccin bestond bij velen de 
overtuiging dat de infectieziekten waren verslagen. De infectieziekten leken bijna weg. Maar pokken werd de enige infectieziekte die is 'verslagen' en dat door middel van vaccinatie. Met het uitbreken van de aids-epidemie in de jaren ' 80 bleek dat het perspectief veel minder rooskleurig was. In de huidige tijd zien we het opkomen van nieuw ontdekte infectieziekten - ook wel emerging infectieziekten genoemd en het opkomen van oude infectieziekten - ook wel re-emerging infectieziekten. ${ }^{4,5}$

Een indrukwekkend voorbeeld van een emerging infectieziekte en een zoönose vanuit vleermuizen was de wereldwijde epidemie door het SARS coronavirus. ${ }^{6}$ In ruim een half jaar tijd van november 2001 tot juli 2002 zorgde verspreiding via reizen zoals te zien is op deze dia tot meer dan 8000 geregistreerde gevallen en zo'n 800 doden.
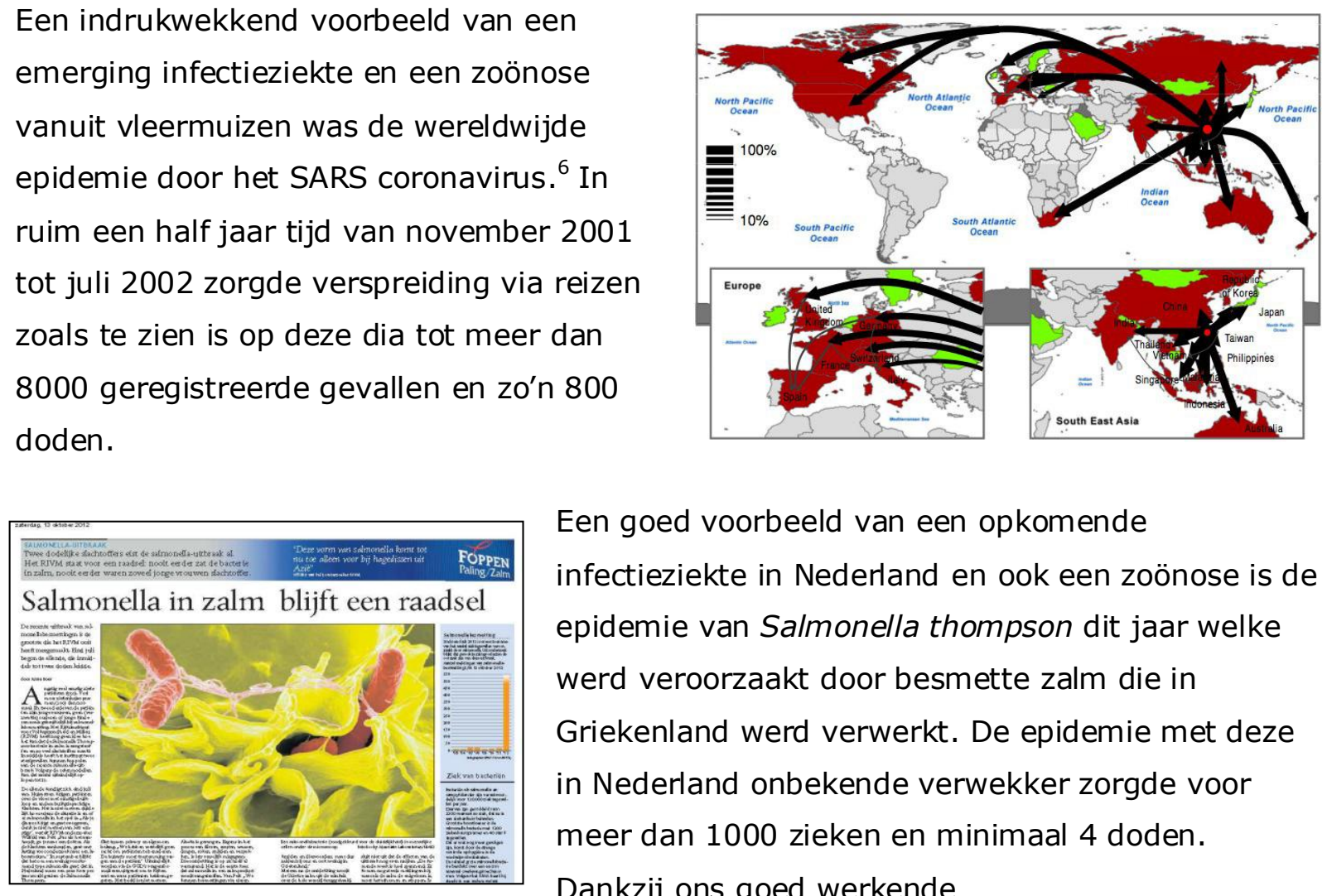

Een goed voorbeeld van een opkomende infectieziekte in Nederland en ook een zoönose is de epidemie van Salmonella thompson dit jaar welke werd veroorzaakt door besmette zalm die in Griekenland werd verwerkt. De epidemie met deze in Nederland onbekende verwekker zorgde voor meer dan 1000 zieken en minimaal 4 doden. Dankzij ons goed werkende infectieziektebestrijdingsstructuur werd de bron door middel van een patiënt-controle onderzoek van Centrum Infectieziektebestrijding van het RIVM en GGDen snel opgespoord en kon dankzij de Nederlandse Voedsel- en Warenautoriteit alle besmette zalm eind september worden teruggeroepen. Dankzij deze maatregelen werd daarmee nog meer ziekte en dood voorkómen. En nee, salmon-ella is niet vernoemd naar haar besmetting in zalm, maar naar haar ontdekker Dr. Daniel Elmer Salmon, een veterinaire patholoog. Op deze ingekleurde elektronenmicroscopische foto - zoals te zien is op de dia - is overigens de veel voorkomende Salmonella typhimurium te zien die hier menselijke cellen binnendringt. 


\section{Q-koorts}

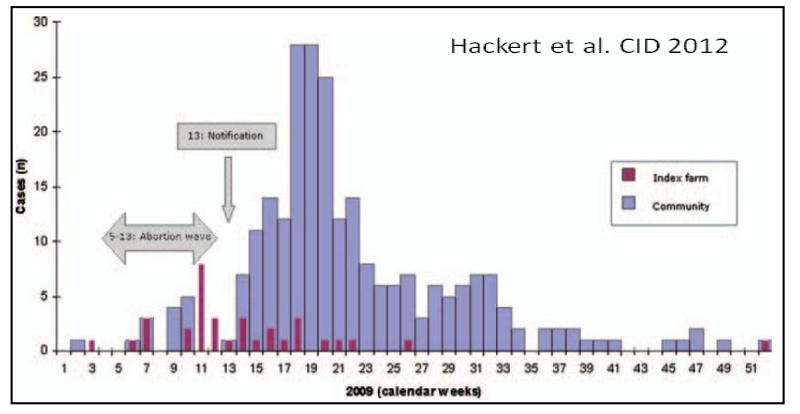

Een andere bekende re-emerging infectieziekte en ook een zoönose is Qkoorts die zoals u weet een grote epidemie in Nederland veroorzaakte tussen 2007 en 2010. In Zuid-Limburg vond één van de wereldwijd grootste uitbraken plaats die uitging van een geïsoleerde bron. ${ }^{7}$ Op een

zorgboerderij kregen begin 2009 bijna de helft van de 450 zwangere geiten een spontane abortus. Aan de geitenboerderij gelieerd werden 59 personen geïnfecteerd met Coxiella burnetti - de Q-koorts bacterie. Vanuit de omgeving werden 253 patiënten door huisartsen gemeld. In de grafiek zijn de eerste ziektedagen van alle geregistreerde gevallen weergegeven. De patiënten in de omgeving werden waarschijnlijk geïnfecteerd doordat de Q-koorts bacterie met de wind mee werd verspreid vanuit de boerderij. In de figuur zie je een kaartje van de Q-koorts verspreiding in de regio Oostelijk Zuid-Limburg met de verschillende mogelijke bronnen als blauwe en groenen vierkanten. De groene vierkantjes zijn schapenhouders en de blauwe vierkanten zijn geitenboerderijen. Het blauwe vierkant met de oranje cirkels betreft de geitenboerderij met de abortusgolf. Op het kaartje is de verspreiding van Q-koorts te zien in de rode punten die één of meer patiënten voorstellen. De meeste gevallen zijn te vinden in de dominante windrichting vanuit de boerderij zoals te zien is in de windroos in de rechter bovenhoek van het kaartje. Hoe donkerder bruin de achtergrond kleur hoe meer patiënten zich bevonden in een ring rond de zorgboerderij. Het vóórkomen van Q-koorts liep uiteen van $6 \%$ in een straal van $1 \mathrm{~km}$ vlak rond de boerderij tot $0,1 \%$ op $5 \mathrm{~km}$ afstand. Op basis van seroprevalentie onderzoek bij mensen voor en na de epidemie - dat is onderzoek naar antistoffen in bloed - was de geschatte werkelijke aantal zieken bijna 9000 infecties op een inwoneraantal van ruim 300.000. Met het geregistreerde aantal van totaal 312 gevallen kunnen we concluderen dat maar een klein deel van de

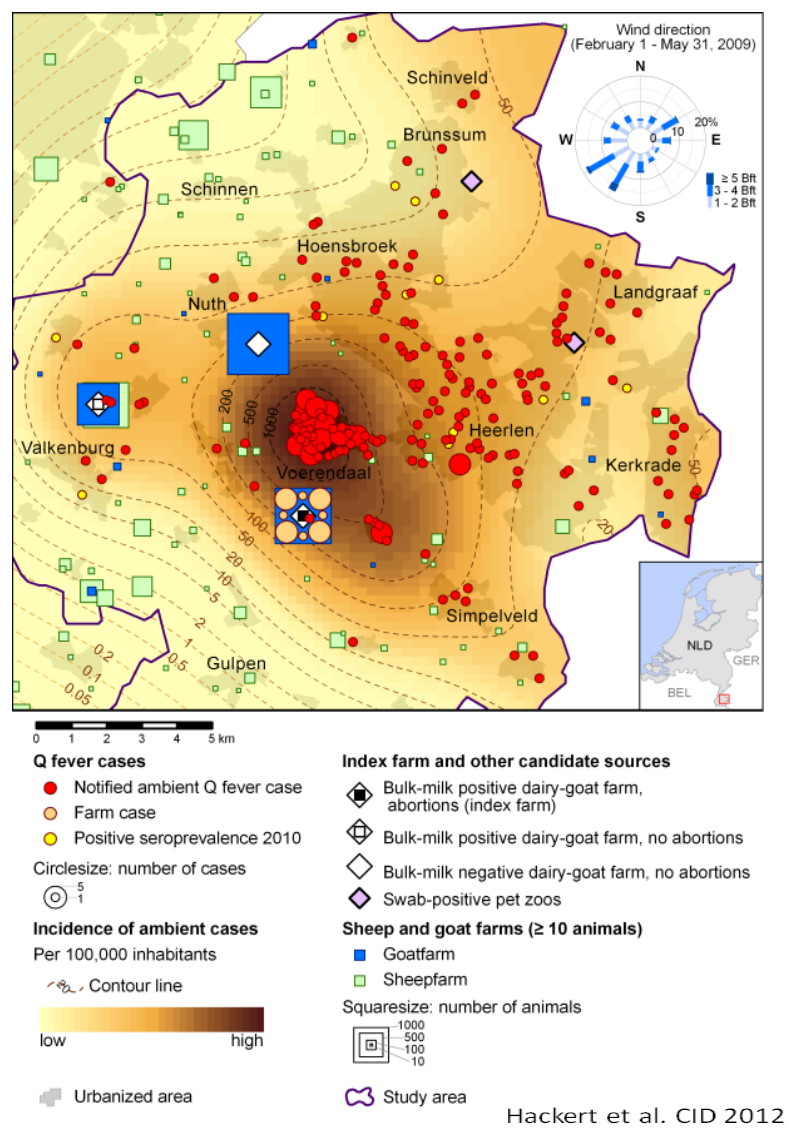


geïnfecteerden medische hulp heeft gezocht. ${ }^{7}$ Ook is duidelijk geworden uit serologisch onderzoek dat er waarschijnlijk zelfs transmissie over de grens naar Duitsland heeft plaatsgevonden op afstanden van meer dan $15 \mathrm{~km}$.

Infectieziekten komen dus volop voor en zelfs bepaalde chronische ziekten zijn herkend als veroorzaakt door infectieziekten, zoals helicobacter pylori bij maagzweren of baarmoederhalskanker dat veroorzaakt wordt door het humaan papilloma virus waarvoor nu alle 12-jarige meisjes in Nederland een vaccinatie krijgen aangeboden.

Nog steeds vormen infectieziekten helaas nummer 1 in de doodsoorzaken statistieken van de Wereld Gezondheidsorganisatie. Deze statistieken worden met name bepaald door 4 infectieziekten uit de top 10: luchtweginfecties, HIV, diarree en tuberculose.

Infectieziekten zouden volgens de WHO verantwoordelijk zijn voor 16 miljoen jaarlijks doden (26\%) van 57 miljoen jaarlijks (2007). De meeste infectieziekten bevinden zich in ontwikkelingslanden en deze dia laat deze ongelijkheid in infectieziektedoodsoorzaken zien. In de paarse delen van de taarten staan de infectieziekten. Veel van deze infectieziekten zijn feitelijk vermijdbaar maar door de complexe factoren waarmee ze samen hangen

\section{Doodszoorzaken}

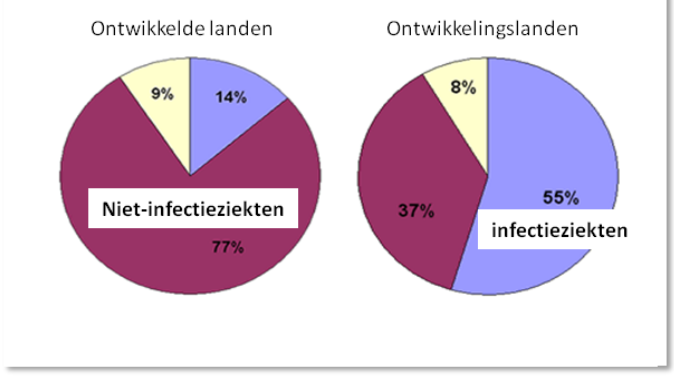
zijn ze helaas vaak niet als geïsoleerd probleem op te lossen. Redenen voor het opkomen van infectieziekten zijn zeer divers en te vinden in genetische, biologische, sociale, politieke en economische determinanten. Factoren die hierbij een rol spelen zijn migratie en verstedelijking, internationale reizen en handel, voedselproductie, afbraak van openbare gezondheidszorg, meer antibiotica gebruik en een complexere wereld met armoede, hongersnood, oorlogen, veranderende ecosystemen, veranderende technologie en industrie, milieuvervuiling en klimaat verandering. Bij HIV en het SARS coronavirus was dit bijvoorbeeld de aanpassing van het virus aan een nieuwe gastheer, bij het influenza ofwel het mexicaanse griepvirus is dit de immunologische druk van de populatie.

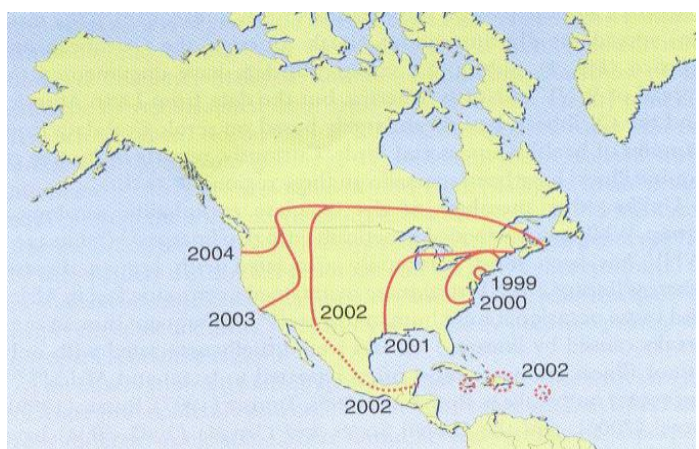

Bij het West-Nijl virus heeft waarschijnlijk vogelmigratie en verandering in klimaat een belangrijke rol gespeeld. Het West-Nijl virus verspreidde zich na 1999 in 5 jaar tijd in de hele verenigde staten zoals op de dia is te zien. In de het kleine kaartje van de verenigde staten linksonderin laat ik zien hoe het virus zich per 
jaar verspreide. Rood betekent hier dat meer dan $10 \%$ van de gevallen in die staat voorkwamen en licht blauw minder dan $1 \%$. Wit betekent dat er geen gevallen waren. Het leidde volgens het CDC in die periode tot bijna 20.000 ziektegevallen en bijna 800 doden. Ook in het zuiden van Europa, zoals in Italië en Griekenland is het West-Nijl virus binnen getreden terwijl het hier vroeger nooit voorkwam. West-Nijl virus kan zich verspreiden via meer dan 100 verschillende muggensoorten waarvan er ook 9 in Nederland voorkomen.

Maar in de afgelopen eeuw is er veel vooruitgang geboekt in de preventie en bestrijding van infectieziekten. Ik denk dan aan de toegenomen hygiëne, verbeterde huisvesting, sanitair en riolering, schoon drinkwater, beschikbaar komen van vaccinatie, antibiotica en antivirale middelen. Toch kunnen we zelfs in westerse landen niet op onze lauweren rusten.

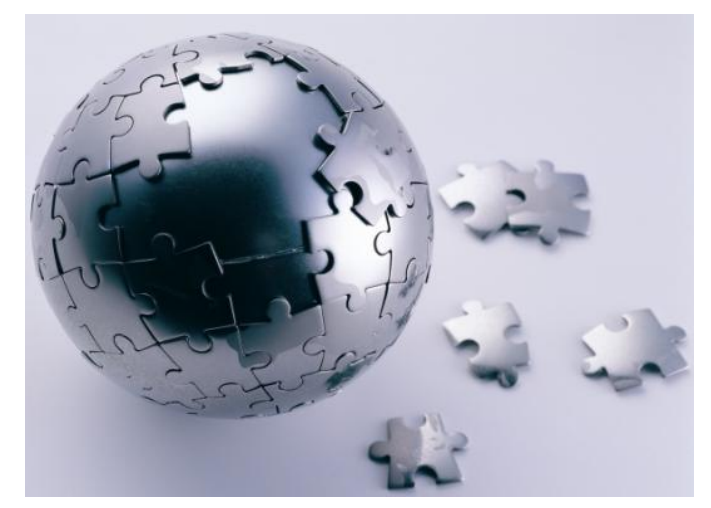

\section{Wat zijn de uitdaging?}

Ik constateer drie grote uitdagingen van deze tijd voor de infectieziektebestrijding:

1. Infectieziekten kennen een voortdurende dynamiek die onvoorspelbaar is en die de infectieziektebestrijders voordurend voor nieuwe vragen stelt. Ook Nederland blijft te maken krijgen met emerging en re-emerging infectieziekten zoals Legionella pneumophila verspreiding door koeltorens, Q-koorts verspreiding door geitenbedrijven, Salmonella Thompson in zalm, EHEC bacteriën in gekiemde zaden en Chlamydia in jongeren. We kunnen ons niet volledig wapenen tegen infectieziektebedreigingen in de toekomst en dat moeten we ook niet pretenderen.

2. Bekende maatregelen zijn niet meer altijd meer even effectief. Er is sprake van een toename van antibioticaresistentie zoals met 'ziekenhuisbacterie' MRSA en 'varkens'MRSA, ESBL-bacteriën vanuit kippen, multiresistentie bij tuberculose en resistentie bij de gonorroebacterie - om maar een paar voorbeelden te noemen. Ook vaccins zijn niet altijd meer helemaal opgewassen tegen hun taak om infectieziekten te voorkomen zoals te zien is aan de vele gevallen van kinkhoest ondanks kinkhoestvaccinatie en de grote aantallen bof onder studenten ondanks hun vaccinatie tegen bof.

3. De maatschappij verandert voortdurend. We leven in een tijd van snelle nieuwe ontwikkelingen met nieuwe media en nieuwe technologieën. Een mondig publiek dat zich met de nieuwe media in de hand op allerlei manieren terecht of onterecht geïnformeerd weet en alleen tevreden lijkt te zijn met een nul-risicolijn vanuit het 
'voorzorgprincipe'. Er bestaat een afnemend vertrouwen in autoriteiten en niet altijd een vanzelfsprekend vertrouwen in aangeboden maatregelen om je tegen infectieziekten te beschermen. Dat bleek bij relatief lage opkomst van de HPV vaccinatie bij 12-jarige meisjes, bij de influenzavaccinatie in de zorg of bij de lage participatie in de chlamydiascreening door jongvolwassenen waar ik later op terug kom.

Daarmee zijn en blijven infectieziekten één van de grote uitdagingen voor de volksgezondheid.

\section{Hoe hebben we het nu geregeld?}

Infectieziektebestrijding is een overheidstaak. In de eerste instantie zijn gemeenten en daarmee GGDen verantwoordelijk voor preventie en infectieziektebestrijding in hun gebied. In de Grondwet is vastgelegd dat de overheid maatregelen moet treffen ter bescherming van de gezondheid van haar burgers. Huisartsen en specialisten zijn de eerste belangrijke schakel in de bestrijding van infectieziekten omdat zij een infectieziekte vaststellen en behandelen en vervolgens melden aan de GGD. Zowel de behandelend arts als de arts-microbioloog heeft een meldingsplicht. Naar aanleiding van een melding verricht de GGD bron- en contactonderzoek en wordt er gezocht naar de besmettingsbron van de infectieziekte en naar mogelijke besmette personen in de omgeving van de zieke. De GGD verricht het bron- en contactonderzoek vaak samen met andere partijen, afhankelijk van de aard van de gemelde infectie. Bij een ziekte die overgedragen kan worden door dieren of voedsel, werkt de GGD samen met de Nederlandse Voedsel- en Warenautoriteit (NVWA). De NVWA kan bij gevaar voor de volksgezondheid ook maatregelen afdwingen, zoals het terugroepen en/of vernietigen van besmette voedingswaren of het ruimen van dieren. Het Centrum Infectieziektebestrijding ( $\mathrm{CIb}$ ) van het Rijksinstituut voor Volksgezondheid en Milieu (RIVM) is regisseur van de landelijke infectieziektebestrijding. Het CIb coördineert bij een bovenregionale epidemieën en het voert de landelijke surveillance van infectieziekten uit. Samen met de GGDen en andere partijen in het veld ontwikkelt zij richtlijnen en draaiboeken voor de lokale en landelijke bestrijding van infectieziekten. Bovendien voert ze met GGDen het Rijksvaccinatieprogramma uit om alle kinderen in Nederland te beschermen tegen gevaarlijke en soms dodelijke infectieziekten. Daarmee is de infrastructuur voor infectieziektebestrijding goed neergelegd en moet deze vooral bestendigd worden.

Ook op het gebied van de soa/hiv-bestrijding hebben we veel bereikt door een duidelijk netwerk van centra voor seksuele gezondheid in Nederland die door 8 GGDen worden 
gecoördineerd. ${ }^{8}$ Er is een goede kwaliteits- en financieringsstructuur voor soapoliklinieken om geïntegreerd preventie en curatie te verbinden. Sinds 2006 is daar tevens het brede kader van de seksuele gezondheid bij jongeren bijgekomen zoals anticonceptie, seksueel geweld, tienerzwangerschappen of seksuele disfuncties. Het is van eminent belang dit succesvolle systeem in stand te houden en zo mogelijk te versterken.

\section{Wat kan beter in de infectieziektebestrijding?}

Ik wil graag drie zaken benoemen die in mijn ogen nog voor versterking vatbaar zijn voor zowel infectieziektebestrijding in de praktijk als voor het wetenschappelijk onderzoek. Waarmee komen de puzzelstukjes op zijn plaats?

1. Ik wil beginnen met investeren in multidisciplinair samenwerken ofwel we moeten meer over onze grenzen heen

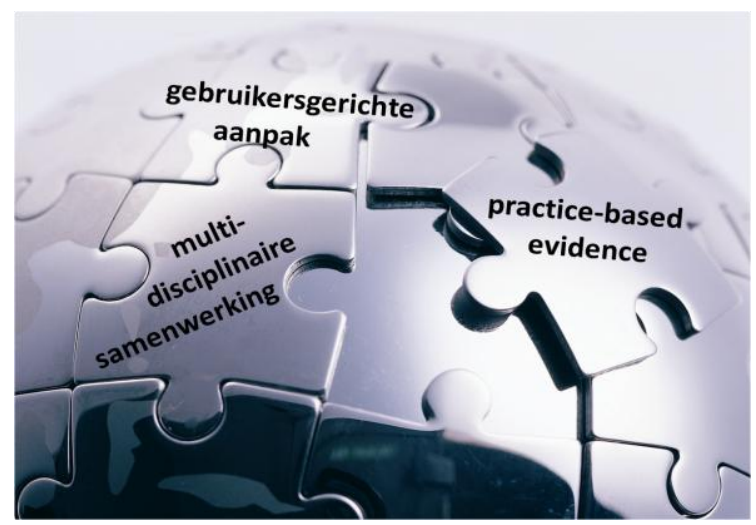
kijken. Multidisciplinaire samenwerking is nodig om hoofd te bieden aan eerder genoemde uitdagingen. We zijn al op veel terreinen op weg om deze bruggen te bouwen. De academische werkplaats waar onderzoek, praktijk en beleid elkaar vinden ofwel in andere woorden de universiteit, de GGD en de gemeenten. Ik ben daarom ook zeer verheugd met de intensieve samenwerking tussen infectieziektebestrijding en medische microbiologie in Maastricht omdat twee belangrijke spelers in de infectieziektebestrijding elkaar zo snel kunnen vinden om innovatie gestalte te geven.

Er mag nog meer worden geïnvesteerd in de 'One Health' gedachte waarbij een brug wordt geslagen in het kader van zoönosen en zo de samenwerking tussen humane en veterinaire geneeskunde gestalte krijgt. Er zijn goede stappen genomen met een landelijk signaleringsoverleg, een vademecum een zoönosen prioriteiten lijst en het Brabants Kennisnetwerk Zoönosen maar de uitwisseling van informatie - liefst realtime - in de praktijk kan nog beter.

Innovatie komt door over vakdisciplines heen onderzoek te doen en ik wil ook graag de samenwerken met vakgebieden als gezondheidsbevordering, psychologie en sociologie bevorderen.

Verspreiding van infectieziekten beperkt zich niet tot nationale grenzen en daarom moeten we ook cross-border samenwerken en letterlijk over de grenzen heen gaan. Infectieziekten kunnen zich vandaag de dag snel over de hele wereld verspreiden. 
Een goede samenwerking tussen internationale instellingen gericht op infectieziektebestrijding is daarom ook van cruciaal belang. Het Europese Parlement heeft daarom in 2004 besloten tot de oprichting van het ECDC. Dit centrum werkt in samenwerking met de nationale centra aan Europese surveillance en signaleringssystemen en wetenschappelijke advisering om zo infectieziektebestrijding in Europa te versterken. Ook samenwerking met landen buiten Europa wordt steeds belangrijker.

Zuid-Limburg ligt in de Euregio en zit voor 95\% van haar grens vast aan België en Duitsland en kan als proeftuin dienen voor deze internationale context. Er zijn al verschillende euregionale projecten waarbij infectieziekten een plaats innemen. Tussen de infectieziektebestrijders in Zuid-Limburg, Duitsland en België bestaat uitgebreide samenwerking, waarbij nu al real-time infectieziektegegevens worden uitgewisseld met onze Duitse buur-GGD in Aken via een digitaal dashbord. ${ }^{9}$

2. Als tweede: User-oriented approach of in beter Nederlands gebruikersgerichte aanpak. Infectieziektebestrijding is meer dan een verzameling medisch-technische interventies. Het vóórkomen en bestrijden van infectieziekten wordt bepaald door menselijk gedrag. Dit betreft niet alleen gedrag van patiënten en medisch en paramedisch professionals, maar ook van politici, bestuurders, geestelijk leiders en mensen uit de bevolking. Infectieziektebestrijding is een maatschappelijke activiteit. Niet elke groep vertoont altijd gedrag dat gebaseerd is op wereldbeelden, mensbeelden, overtuigingen of belangen die stroken met een medisch-technisch bewezen effectieve bestrijding. Dat betekent dat infectieziektebestrijders zich voortdurend in hun communicatie, maatregelen en wetenschappelijk onderzoek rekenschap moeten geven van de kijk van zorgprofessionals, bestuurders, media en burgers. Hoe betrekken we burgers bij de infectieziektebestrijding en het onderzoek? Hoe realiseren we een betekenisvolle en effectieve communicatie? Ik denk dat we de verantwoordelijke burger onderdeel moeten maken van de oplossing en hen meer dan in het verleden moeten betrekken bij communicatie en maatregelen. We moeten 'ervaringsdeskundigen' bij het ontwerpen van maatregelen en interventies betrekken en communiceren op het taalniveau van de ontvanger. Daarom pleit ik voor een gebruikersgerichte aanpak om effectiever maatregelen vorm te geven.

3. En als derde Practice-based evidence. Doen we de dingen juist? Doen we de juiste dingen? Weten we of dat wat we doen ook werkt in de praktijk? Een sterke wetenschappelijke inbreng in de infectieziektebestrijding is noodzakelijk om deze vragen te beantwoorden, zowel om onze kennis op het gebied van nieuwe en veranderende infectieziekten op peil te brengen en verder te verdiepen, als om te 
komen tot een wetenschappelijk onderbouwde aanpak van preventie en bestrijding. Bovendien kan wetenschappelijk onderzoek een zeer belangrijke bijdrage leveren aan inzichten in de infectieziekteketen van reservoir naar micro-organisme naar transmissie en gastheer. Het is daarbij een uitdaging om onderzoek en praktijk samen te laten optrekken, waarbij onderzoeksresultaten snel moeten kunnen worden vertaald naar praktische toepassing. We hebben een goede onderzoeksketen nodig om practice-based evidence interventies en maatregelen te kunnen nemen. We willen oorzaken begrijpen, strategieën identificeren en impact evalueren. Dit gaat dus verder dan bewijs voor effectieve interventies die in gecontroleerde omstandigheden zijn verzameld.

\section{Model Infectieziektebestrijding $\mathbf{2 . 0}$}

Daarom verdient de infectieziektebestrijding een nieuwe onderzoeksvisie Infectieziektebestrijding 2.0 waarin bovengenoemde 3 puzzelstukjes een plek krijgen. We willen met infectieziektebestrijdingsonderzoek kennis ontwikkelen om de gezondheid van de bevolking maximaal bevorderen. Dit onderzoek verdient echter een bredere visie dan gebruikelijk bij klinisch onderzoek - zoals eerder is betoogd door Ogilvie ${ }^{10}$ voor openbare gezondheidsonderzoek. Vanuit een brede visie wil ik daarmee komen tot een translationeel raamwerk voor infectieziektebestrijdingsonderzoek. In translationeel klinisch onderzoek wordt hiermee bedoeld de vertaling van inzichten uit het fundamentele onderzoek naar klinisch onderzoek naar klinische toepassingen in de zorg zoals beschreven in het RGO rapport van 2006. Het gaat hierbij om een lineaire keten waarbij bewijs ofwel evidence wordt geleverd in gecontroleerde omstandigheden in een specifieke groep patiënten. Dit klinisch onderzoeksmodel kent echter een aantal beperkingen. Ik zal de vier stappen van de klinische onderzoeksketen nemen als basis van deze nieuwe visie en als start nemen van het bredere model dat gebaseerd is op dat van Ogilvie. ${ }^{10}$

Epidemiologie is de basis discipline binnen de infectieziektebestrijding. In de klassieke epidemiologische visie zorgen beschrijvende studies voor hypothese vorming ofwel werkingsmechanismen begrijpen van factoren die een rol spelen. Antwoord op de vraag: Waarom zou iets kunnen werken? Deze gegevens leiden naar analytische ofwel hypothese testende studies die gebaseerd zijn op cohort en case-control onderzoeksdesign om risicofactoren of determinanten te identificeren die bijdragen aan ongezondheid of gezondheid in de populatie of in subpopulaties. De vraag is dan: Welke factoren spelen een rol? Sterk bewijs kan een aanwijzing zijn voor een oorzakelijke relatie afhankelijk van biologische plausibiliteit, tijdsrelatie en dosisrespons relatie en kan binnen infectieziekteonderzoek worden aangevuld met microbiologische typering ofwel 
eenzelfde micro-organisme in bron en zieken. De gevonden risicofactoren zijn vervolgens de input voor de selectie, ontwikkeling en evaluatie van innovatieve strategieën of nieuwe interventies die deze risicofactoren willen beïnvloedden. De vraag wordt beantwoord: Hoe kunnen we de factoren beïnvloeden? Dit kan direct op determinanten van gezondheid of indirect door het beïnvloeden van determinanten van individueel gezondheidsgedrag die daarmee de gezondheid beïnvloed. Voor het infectieziektebestrijdingsonderzoek reflecteert de onderzoeksketen een spectrum van determinanten: van beïnvloedbare risicofactoren op het individuele niveau tot sociale en omgevingsdeterminanten van gezondheid op collectief niveau.

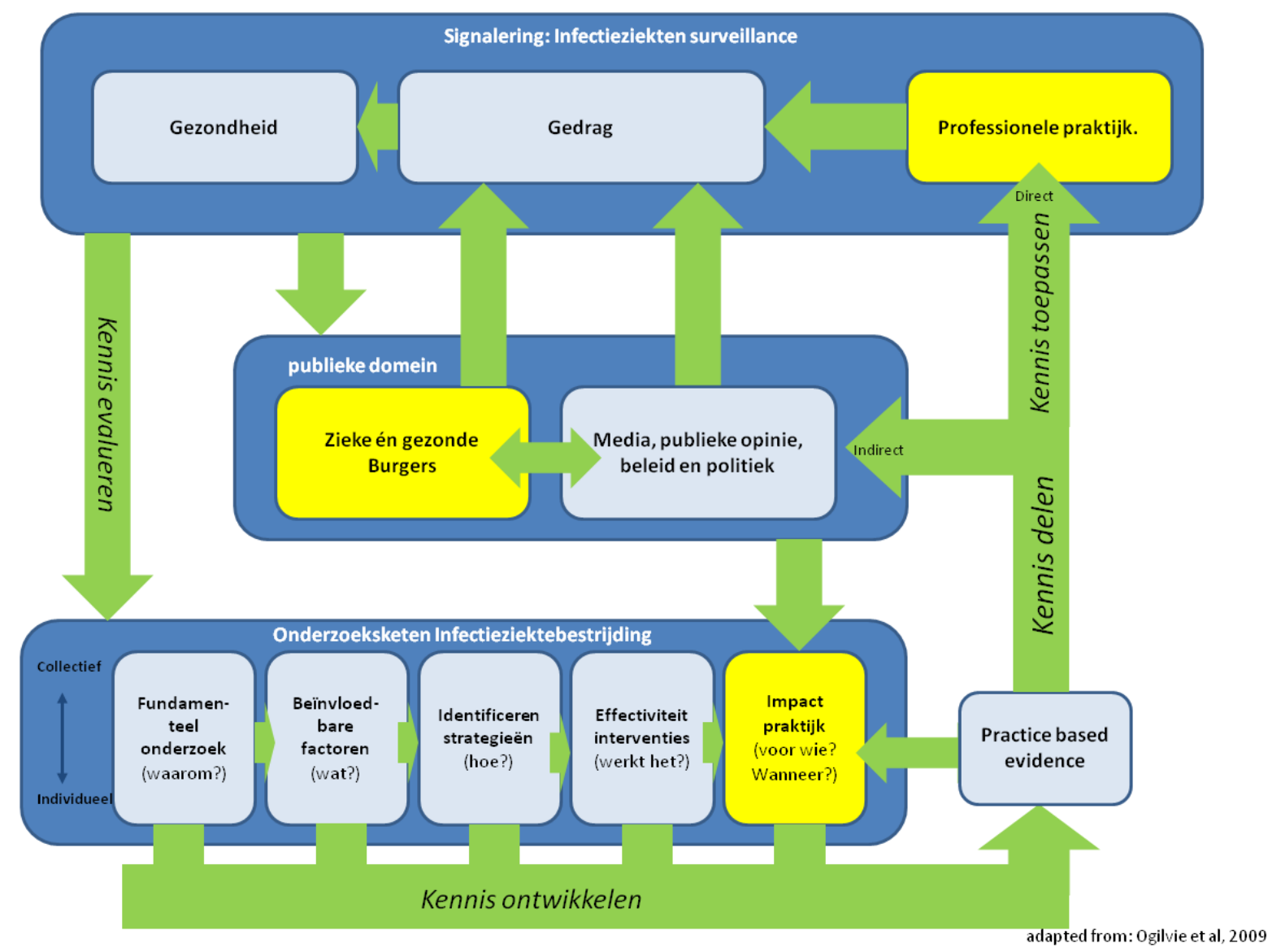

Het eindpunt in de klinisch onderzoeksketen is vervolgens het implementeren van therapeutische of diagnostische interventies in de routine klinische praktijk die effectief verklaard zijn in gecontroleerde omstandigheden. Ook in de onderzoeksketen van de infectieziektebestrijding moet de vraag - of een preventieve interventie effectief is gesteld worden. Daarmee wordt de vraag beantwoord: Werkt het? Daarbij is een spectrum aan niveaus van interventies mogelijk waarbij een brug geslagen kan en moet worden naar zeer diverse vakgebieden van biomedisch georiënteerde vakgebieden als de medische microbiologie, kindergeneeskunde, interne geneeskunde en diergeneeskunde naar meer sociale wetenschappen zoals psychologie, gezondheidsbevordering, 
communicatie wetenschappen en gezondheidseconomie tot het vakgebied van 'health technology assessment'. Voor onderzoek in de openbare gezondheidszorg is deze vierde stap in de onderzoeksketen echter onvoldoende als eindpunt omdat de verbetering van populatie gezondheid het einddoel is - ofwel wat is de impact van de interventie in de populatie? Dit einddoel kan op korte termijn veranderingen in gezondheidsgedrag of andere risicofactoren betekenen en op de langere termijn vermindering van ziekte, dood of verbetering van kwaliteit van leven. Dit impliceert twee zaken: 1. De noodzaak één stap toe te voegen aan de onderzoeksketen door de effectiviteit van interventies in de praktijk uit te testen en te komen tot 'practice based evidence' - dus antwoord op de vragen: Voor wie werk het? En wanneer? En tegen welke kosten? en 2. De noodzaak van een 'feedback loop' waarbij populatie surveillance data nodig is die bijdraagt aan de beschrijvende epidemiologie van de condities en risicofactoren in de populatie, zoals die nu voor infectieziekten veelal wordt uitgevoegd door het Centrum Infectieziektebestrijding. Door kennis gebaseerd op practice-based evidence te delen en toe te passen in de professionele praktijk kan gezondheidsgedrag en gezondheid positief beïnvloed worden. Evaluatie van signalen uit de professionele praktijk en surveillance kan weer input zijn om op individueel of collectief niveau nieuwe hypotheses te ontwikkelen. Hiermee ontstaat een cyclus van voortdurende innovatie en doen we ons werk steeds beter.

Echter, we bevinden ons met dit onderzoekswerk niet op een eiland en een component die vaak nog erg onderbelicht is in de onderzoeksketen is de maatschappelijke component. Infectieziektebestrijding vindt plaats midden in de maatschappij - in de publieke arena waar een centrale rol is weggelegd voor de burger met daaromheen de media, het beleid en de politiek. Gezondheidsbeleid, media en politiek beïnvloedden immers het gedrag van burgers. Kennis moet daarom ook worden gedeeld met beleidsmakers en media. In dit raamwerk wordt daarin de burger expliciet meegenomen naast de maatschappelijke context.

Daarmee heeft de infectieziektebestrijding en haar onderzoek op alle plekken in het raamwerk een rol, en heeft ook onderzoek naar bijvoorbeeld de rol van de media in de publieke opinie rondom Q-koorts een plaats. Het is echter nog een grote uitdaging de burgers of 'gebruikers' bij deze kennisontwikkeling in de onderzoeksketen te betrekken. Het is echter noodzakelijk om de impact van interventies te laten slagen en dit kan niet zonder daarbij de gebruiker op één of andere manier te laten meedenken. Kennisontwikkeling welke input meeneemt vanuit een breder perspectief - zowel maatschappelijk als multidisciplinair - is beter in staat om antwoorden te geven die er toe doen. 
Kenmerken van dit raamwerk zijn dus: het eindpunt niet bij effectieve interventies leggen maar bij verbetering van de populatie gezondheid, omarming van multidisciplinaire samenwerking, betrekken van de burger in de maatschappelijke arena en een herhalend bi-directioneel cyclisch proces met als doel om te komen tot 'practicebased evidence' of wel impact in the real world.

\section{Case studie chlamydia}

Graag geef ik een voorbeeld uit de praktijk met een case studie over chlamydia. De manier waarop we de afgelopen vijftien jaar getracht hebben om beleid rondom chlamydia in Nederland gestalte te geven, is een mooi voorbeeld van een systematische zoektocht naar practice-based evidence. Tegelijkertijd geef ik hiermee een illustratie van het onderzoek en innovatie waaraan ik met mijn leerstoel wil bijdragen.

Infectie met Chlamydia trachomatis is de meest voorkomende bacteriële seksueel overdraagbare infectieziekte ofwel soa in Nederland. De infectie is breed verspreid en bij jongeren tussen de 15 en 25 jaar komt deze het meest voor. Een ongecompliceerde chlamydia-infectie is goed te behandelen met éénmalig 1gr. Azithromycine. Meestal merkt men niets van een chlamydia-infectie en daardoor gaat niet iedere geïnfecteerde naar de huisarts of GGD soa-poli om zich te laten testen en te laten behandelen. Bij vrouwen kan de bacterie opstijgen naar de eileiders. Er ontstaat een eileiderontsteking die zich kan uitbreiden naar de buikholte. Wordt de eileiderontsteking niet of te laat behandeld, dan komen er littekens in de eileiders en kan de eileider verstopt raken. Dit kan leiden tot onvruchtbaarheid, een buitenbaarmoederlijke zwangerschap of tot chronische buikpijn. Chlamydia kan tijdens de bevalling overgedragen worden aan de baby. De baby kan hierdoor een oogontsteking of longontsteking krijgen. Ook bij mannen kan de ontsteking opstijgen. De bacteriën kunnen via de zaadleiders terecht komen in de prostaat en de bijbal. Dit kan leiden tot een bijbalontsteking.

Naar schatting zijn er in Nederland elk jaar tussen de 80.000 en 100.000 nieuwe chlamydia-infecties, waarvan er 60.000 plaatsvinden bij jongvolwassenen tussen de 15 en 30 jaar. ${ }^{11}$ Anno 2011 worden jaarlijks volgens RIVM cijfers bijna 250.000 chlamydiatesten uitgevoerd bij de twee belangrijkste aanbieders van chlamydia-testen: op de GGD soa-poliklinieken 115.000 testen en bij huisartsen 130.000 testen. ${ }^{12}$ Onder bezoekers van de GGD soa-poli's (ofwel centra voor seksuele gezondheid) wordt bij $11 \%$ een chlamydia-infectie gevonden. Bij jongeren loopt dit zelfs op tot $15 \%$. Dit testgedrag bij GGD soa-poli en huisarts leidt in Nederland op basis van RIVM en huisartsen-netwerk LINH in 2011 tot ruim 40.000 opgespoorde gevallen van Chlamydia, waarvan 26.000 
onder jongeren tussen 15 en 30 jaar. ${ }^{13}$ Dat betekent dat nog steeds de helft van alle chlamydia niet wordt opgespoord.

In de afgelopen 15 jaar bracht de jaarlijkse toename van chlamydia-infecties de vraag naar chlamydiascreening op de agenda. De Gezondheidsraad constateerde in 2004 dat de gegevens over de verspreiding van chlamydia en het niveau van de bewijskracht te beperkt waren. Vier GGD'en en Soa-Aids Nederland starten een pilot bevolkingsonderzoek - de PILOT Chlamydia - onder 21.000 mannen en vrouwen van 15 tot 30 jaar. Het voorkomen van chlamydia in de bevolking bleek 2 procent te zijn en varieerde van 0,6 procent in plattelandsgebieden tot 3,2 procent in sterk verstedelijkte gebieden, met hogere percentages onder specifieke risicogroepen zoals jonge vrouwen, personen met meerdere partners en Surinaamse en Antilliaanse personen. ${ }^{11}$ Uit dit onderzoek bleek dat selectieve screening een uiterst kosteneffectieve interventie zou zijn. ${ }^{14}$ Ook buitenlandse modelleringsstudies suggereerden dat met 'home based screening' binnen enkele jaren de prevalentie drastisch kon worden teruggebracht. ${ }^{15}$ Daarmee leek chlamydia een hele goede kandidaat om te komen tot een nieuw screeningsprogramma.

Daarom startte in 2007 het grootschalige Chlamydia Screening Implementatie project: CSI, een samenwerking van 3 GGDen, Soa-Aids Nederland en het RIVM. Alle ruim 300.000 16-29 jarige vrouwen en mannen ingeschreven in het bevolkingsregister in de drie interventieregio's Amsterdam, Rotterdam en Oostelijk Zuid-Limburg ontvingen jaarlijks een persoonlijke uitnodiging via de post. De thuistest kon via internet besteld worden, in Zuid-Limburg overigens pas na triage op internet via een risicoscore. Dit was de uitwerking van de eerder genoemde selectieve screening. De hoop was dat met dit extra screeningsaanbod naast de chlamydia testen in de reguliere zorg voldoende getest zou worden om echt impact te hebben op de chlamydia verspreiding. Het screeningsprogramma op zich draaide erg goed met de ondersteunende software waarvoor zelfs de Spideraward 2009 gewonnen werd voor het meest innovatieve zorgprogramma van dat jaar.

De resultaten waren echter minder positief dan we op basis van het bestaande bewijs en literatuur was verwacht. De initiële participatie was lager dan in het eerdere PILOT onderzoek en daalde ook nog eens

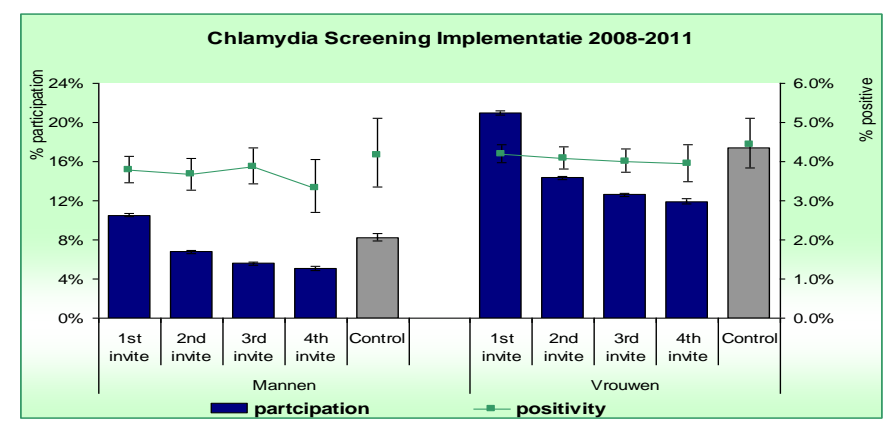
per ronde - op de dia te zien voor mannen en vrouwen. Voor alle participanten ging dit van 16 procent na de eerste uitnodiging naar 10 procent in het derde jaar. In de interventieclusters waren het percentage gevonden chlamydia-infecties en de geschatte 
prevalentie na drie uitnodigingen nauwelijks lager, al waren er wel aanwijzingen voor een dalende trend in Zuid-Limburg en werkte de selectieve screening hier positief. ${ }^{16}$ Onder personen die alle drie de ronden deelnamen daalde het percentage infecties overigens wel significant van 6 procent naar 3 procent, maar dit betrof nog geen 3 procent van alle uitgenodigden. Hoewel het voor iedere deelnemer die positief was gezondheidswinst opleverde op individueel niveau was dit niet de impact die we gehoopt hadden op collectief niveau. Modellering liet beperkte impact op het geschatte vóórkomen zien na tien jaar, waardoor de kosteneffectiviteit ongunstig uitviel en sterk afweek van modellering met data uit eerdere meer kleinschalige en kortere trials met veel gunstiger uitkomsten. ${ }^{17}$ De practice-based evidence liet zo zien dat chlamydiascreening in deze vorm niet uitgerold diende te worden. ${ }^{18}$

Bewijs vanuit gecontroleerde situaties zoals die zich in randomized-controlled trials voordoen, komt niet altijd overeen met de 'real world' en daarom is het belangrijk om die extra stap in de onderzoeksketen te zetten om voldoende practice-based evidence te hebben voordat een nieuw preventieprogramma wordt geïmplementeerd.

Maar dan zijn we er nog niet. De huidige zorg mist nog steeds een hoop Chlamydia terwijl de complicaties potentieel ernstig zijn. Nu de populatiescreening niet de oplossing blijkt te zijn is de vraag wat dan te doen. Hoe kunnen wij een effectieve manier vinden om de verborgen populaties te benaderen om de preventie in optimaliseren. De eerste uitdaging is nu het vinden van de verborgen doelgroepen, de tweede uitdaging is hun de benodigde zorg te leveren van testen, behandeling en counseling. Het effect en de impact van deze zorg op preventie hangt sterk af van de gekozen strategieën om de juiste zorg op de juiste tijd aan de juiste - geïnfecteerde mensen te leveren. De reguliere zorg, zoals huisarts, ziekenhuis en GGD is in hoge mate afhankelijk van symptomatische ziekte en richt zich met name op brede doelgroepen, de zogenaamde risicogroepen die bepaald zijn op basis van gedrag en leeftijd. Dit zijn conventionele epidemiologische determinanten die lange tijd gebruikt zijn om het risico te bepalen. Voorbeelden van deze risicogroepen zijn mannen die seks hebben met mannen en jongeren. Echter, binnen deze brede populaties bestaat een grote diversiteit in het risico op infectie waardoor zorg onnodig terecht komt bij mensen die minder risico lopen. Dat de meeste chlamydiainfecties asymptomatisch verlopen en derhalve onopgemerkt blijven, zorgt ervoor dat geïnfecteerden geen of laat medische zorg zoeken. We weten dat chlamydia zich verspreid via seksuele netwerken. Recent werk met behulp van economische en dynamische netwerkmodellen bevestigt dat interventies gericht op mensen die een hoog risico lopen meer opbrengen. ${ }^{19-22}$ Aangezien de balans tussen kosten en baten steeds belangrijker wordt, zijn de mensen die een hoog risico hebben op chlamydia en geen zorg krijgen van cruciaal belang voor testen, behandeling en counseling. Recent werd het 
concept van

'sleutelpopulaties'

voorgesteld als strategie

om de beperkingen in de

HIV-controle in Afrika te

overwinnen met de focus

op seksuele netwerken en

de epidemische status. ${ }^{19}$,

${ }^{23}$ De populatie die ik
In Zorg

Niet in Zorg

\section{GÉÉN RISICOGROEP}

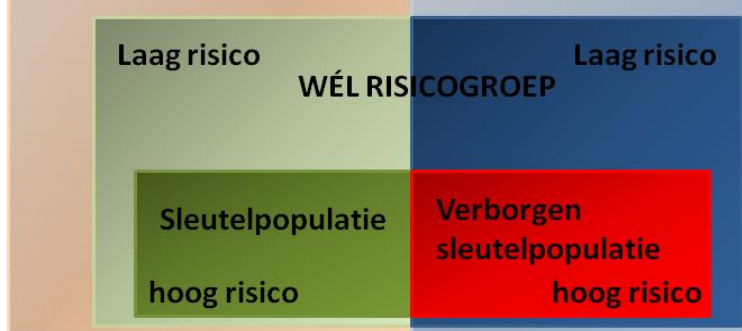

Laag risico

Laag risico

beschrijf willen we daarom de 'verborgen sleutelpopulatie' noemen. Zoals in de figuur is te zien zijn er patiënten met Chlamydia in zorg en niet in zorg. Een deel hiervan is géén risiscogroep en een deel wel. Een deel hiervan heeft een laag risico en een deel een hoog risico. Deze 'verborgen sleutelpopulatie' wordt nu niet specifiek benaderd binnen de huidige zorg- en preventiestrategieën. Een nieuwe interventie om de chlamydiabestrijding op een hoger plan te tillen zou zich daarom op die 'verborgen sleutelpopulatie' moeten richten. Een sleutelpopulatie voor een bepaalde infectie bestaat uit mensen die óf geïnfecteerd zijn óf een hoog risico lopen om de infectie op te lopen. Wanneer men tot een seksueel, sociaal en/of geografisch netwerk met een hoog risico behoort, dan is dit de reden voor het hebben van een hoog risico op een infectie. ${ }^{24,25}$ Chlamydia-infecties gedijen binnen zulke netwerken omdat ze de randvoorwaarden voor transmissie leveren en gebruik maken van het inherente risicogedrag en de sociale en geografische nabijheid. Momenteel blijft een beduidend aantal leden binnen zo'n netwerk volledig verborgen voor de zorg en zijn dus niet getest en blijven onbehandeld, waardoor chlamydia zich blijvend kan verspreiden. Het is tot nu toe onbekend welke praktische zorgstrategieën effectief zijn om de 'sleutelpopulaties' te benaderen, laat staan de 'verborgen sleutelpopulaties'. Binnen ons onderzoek richten we ons daarom nu enerzijds op de kenmerken en grootte van de sleutelpopulaties voor onder andere chlamydia in Zuid Limburg (de wat? vraag) en anderzijds op de ontwikkeling van een volledig nieuwe strategie in zorgaanbod.(de hoe vraag?) Wij ontwikkelen een outreach-interventie die via internet de zorg aan de verborgen sleutelpopulaties biedt. De chlamydia zorg wordt aangeboden via personen binnen de hoog risicogroep die wel gebruik maken van de zorg, namelijk diegenen die met chlamydia geïnfecteerd blijken na een test. We boren als het ware het bestaande chlamydia netwerk aan met onze interventie. ${ }^{26}$ Deze strategie zal eerst voor chlamydia worden uitgetest (de werkt het vraag? En werkt het in de praktijk vraag?) maar is bij gebleken succes veel breder toepasbaar zowel in de publieke gezondheid als bij de huisartsenzorg. Deze innovatieve strategie maakt maximaal gebruik van één van de belangrijkste motivatoren van gedragsverandering: peerinfluence ofwel de invloed van vrienden. ${ }^{27,28}$ Daarom is de werktitel van deze interventie 
en website ook 'safe-friends'. Dit idee sluit ook mooi aan bij de massamediale campagne van Soa Aids Nederland in 2006 die hiernaast is te zien. $\mathrm{Er}$ is hier stelletje te zien dat een nieuwe relatie aangaat maar niet lijkt door te hebben dat er nog vele ongeteste 'oude vrienden' achter hen zitten die ook een soa kunnen hebben.

In deze innovatieve e-health interventie zullen Chlamydia geïnfecteerde jongeren

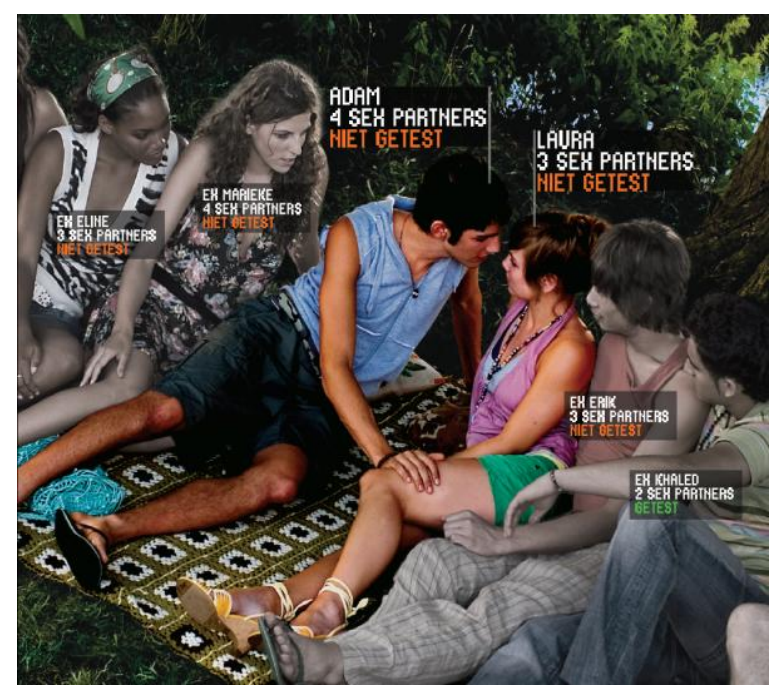
die wel in zorg zijn hun eigen seksuele en sociale netwerkleden motiveren om hetzelfde gedrag te vertonen als henzelf, namelijk zich te laten testen op chlamydia. Deze kettingreactiemethode wordt Respondent Driven Sampling (RDS) genoemd. Dit is een relatief nieuwe, maar reeds wereldwijd gebruikte methode om verborgen populaties te bereiken die nog nooit is toegepast op chlamydiabestrijding met gebruikmaking van software op maat. ${ }^{29,30,31}$ Daarbij maken we volop gebruik van de lessen die we van de chlamydia screening hebben geleerd en combineren we een op het publiek gerichte innovatieve web-based applicatie voor werving en een soa-zorgapplicatie voor de professionals voor patiëntenbeheer. Jongeren met chlamydia die onze soa-polikliniek bezoeken worden door de soa-verpleegkundige bijgestaan in het motiveren van vrienden (sociale netwerken) en sekspartners (seksuele netwerken), die op hun beurt thuis testen via een postpakket, counseling en zo nodig behandeling krijgen aangeboden; dit alles via een openbare applicatie. Netwerkleden worden op een veilige en betrouwbare manier benaderd en communicatie wordt gefaciliteerd door een ondersteunende en veilige omgeving. De persoon die werft, treedt hierbij op als een positief rolmodel - hij of zij heeft immers reeds getest en motiveert anderen - wat de ervaren sociale norm om hetzelfde te doen vergroot. Jongeren ontvangen en delen informatie over soa en testen met peers en met name die vrienden die zij inschatten als hoog risico. Zowel professionele gebruikers als chlamydia positief geteste jongeren en niet geteste jongeren zijn nauw betrokken bij de ontwikkeling en implementatie van deze nieuwe interventie waardoor we de gebruikersgerichte aanpak volgen. Hierdoor sluit de interventie zoveel mogelijk aan bij de doelgroep. Deze e-health interventie is opgezet met de intervention mapping methodiek en de daadwerkelijke implementatie zal waarschijnlijk in 2013 plaatsvinden.

Een van de taken van de GGD is om soa te bestrijden en daarom voert ze op individueel niveau testen en behandeling uit om op collectief niveau verspreiding te beperken. Maar doen we genoeg? Bovenstaande interventie kan mogelijk een additioneel effect hebben 
op datgene wat al binnen de reguliere zorg wordt gedaan. Maar er zijn meer zaken binnen de chamydia-zorg die onze aandacht vragen. Zowel binnen CSI als binnen de regulier zorg zien we een hoog percentage herinfecties. Uit ons eigen onderzoek bleek dat tussen de 15-19 procent van de patiënten bij huisartsen, op de soa-poli of bij gynaecologen binnen één jaar weer Chlamydia geïnfecteerd waren. ${ }^{32}$ Maar het percentage om chlamydia positieven opnieuw op te roepen tussen de drie maanden en een jaar waren laag met tussen de 23 en 33\%. Hierbij liet CSI zien dat het sturen van een chlamydia-thuispakket na een half jaar erg effectief kon zijn daar $66 \%$ meedeed. Hoe goed is ons case-management eigenlijk? Hoe effectief is onze behandeling daadwerkelijk? en hoe goed zijn we in staat herinfecties door onbehandelde partners te voorkomen? En zolang we geen automatische behandeling mogen meegeven aan de partner, hoe kunnen we dan partnerwaarschuwing en vooral partnerbehandeling effectiever maken? Wellicht met behulp van internet en chlamydia thuistest pakketjes? Hoe zorgen we dat chlamydia geïnfecteerden zich weer opnieuw laten testen? Nu duurt het toch nog enige dagen voordat een patiënt zijn uitslag krijgt waarin nog verspreiding kan optreden. Soa-bestrijding wordt effectiever als we deze kostbare tijd niet verloren laten gaan. We lieten zelf helaas zien dat chlamydia sneltesten vooralsnog erg slechte kwaliteit hebben ${ }^{33}$, maar technologische ontwikkelingen kunnen in de toekomst mogelijk deze vertraging verkleinen? Kortom, voortdurend vragen vanuit de praktijk om de soabestrijding effectiever te maken. Vragen die vooral door artsen en verpleegkundigen vanuit de praktijk gesteld kunnen worden en waar we in het wetenschappelijk onderzoek dan valide antwoorden op kunnen krijgen om daarmee de infectieziektebestrijding weer een stap verder te helpen. Een sterke onderzoeksbasis voor de infectieziektebestrijding is dus essentieel om te innoveren en ons werk beter te kunnen doen.

Dan kom ik aan mijn slotwoord

\section{Infectieziektebestrijding 2.0, nieuwe wegen, nieuwe kansen!}

De preventieve strijd tegen infectieziekten is nog lang niet uitgestreden en er dienen zich voortdurend nieuwe vraagstukken aan. We hebben een prachtig systeem voor infectieziektebestrijding dat ook vooral zo moet blijven en niet moet worden afgebroken door mogelijke bezuinigingen. Landen waarbij het public health systeem is aangetast hebben laten zien hoe desastreus dat kan zijn. We kunnen echter nog meer bereiken als we krachten bundelen. Als we ons richten op practice-based evidence in het wetenschappelijk onderzoek, als we in staat zijn de multidisciplinaire samenwerking te optimaliseren en over onze schaduw heen kunnen stappen en bruggen kunnen bouwen naar ketenpartners en ook de burger betrekken bij de infectieziektebestrijding, dan 
kunnen we de uitdagingen van deze tijd aan. Dan zijn we in staat adequaat te handelen bij emerging en re-emerging infectieziekten, antibiotica resistentie, staan we midden in de maatschappij, en bewegen we mee met nieuwe media en nieuwe technologieën.

\section{DANKWOORD}

Voordat ik mijn rede afsluit, spreek ik graag mijn dank uit aan allen die mijn benoeming mogelijk hebben gemaakt. Het feit dat ik hier sta beschouw ik als een grote eer en had ik nooit kunnen bereiken zonder de toegewijde hulp en steun van velen. Malcolm Gladwell vertelt in zijn boek 'the story of success' dat outliers - diegenen met succes - dat vooral te danken hebben aan kansen en mogelijkheden die ze gekregen hebben door anderen. Daar sluit ik me nederig bij aan. Hoewel me de tijd ontbreekt om iedereen persoonlijk te noemen wil ik dat voor een aantal personen wel doen.

Allereerst wil ik de Universiteit Maastricht, faculteit Health, Medicine en Life Sciences danken voor mijn benoeming. Ik wil graag mijn begeleidingscommissie bedanken:

Cathrien Bruggeman, dank zij jou is er een hele sterke en unieke verbinding ontstaan tussen de afdeling infectieziektebestrijding van de GGD en de afdeling Medische Microbiologie van het MUMC. Je hebt je hier altijd met veel passie voor ingezet. Voor jouw bijdrage hierin en je inzet om mijn benoeming mogelijk te maken ben ik je veel dank verschuldigd. I $k$ heb veel geleerd van je scherpe en originele observaties en je menselijke maar tactisch opereren binnen de academische wereld. Je bent recent opgevolgd door Paul Savelkoul. Paul, ik wil je nu al bedanken voor onze positieve start waarbij je volop de ingezette samenwerking ondersteunt en verder helpt uitbouwen.

Fons Bovens en ook Frank Klaassen, twee directeuren van de GGD Zuid Limburg wil ik hartelijk bedanken voor de ruimte die jullie me hebben gegeven onderzoek te doen binnen de GGD en de belangrijke ondersteuning van mijn benoeming. Ik waardeer het zeer dat jullie innovatie en academisering niet alleen mogelijk hebben gemaakt binnen de GGD, maar ook als speerpunt hebben verheven in het GGD beleid. Jullie hebben hiermee onderkent dat innovatie een belangrijke motor is van een gezonde GGD, zodat deze klaar is voor de uitdagingen die op haar weg komen.

Onno van Schayck, directeur van onderzoeksschool CAPHRI wil ik bedanken voor het vertrouwen en de steun voor deze leerstoel. Albert Scherpbier, decaan van de faculteit FHML, en ook zijn voorganger en huidig lid van de raad van Bestuur Martin Paul wil ik daarbij bedanken voor het in mij gestelde vertrouwen. Mijn eerste wetenschappelijke artikelen - over medisch onderwijs - schreef ik met Albert waardoor de cirkel mooi rond 
is. Ik zal mij met veel plezier inzetten in deze nieuwe wetenschappelijke functie. Het is prachtig dat het vakgebied infectieziektebestrijding binnen de faculteit en de onderzoeksschool voor het eerst officieel is vertegenwoordigd. Met deze leerstoel hoop ik een positieve impuls te geven aan de nieuwe wegen die de infectieziektebestrijding nodig heeft.

Ik heb vandaag de eer om even in het licht te staan en heb resultaten van projecten en onderzoeken mogen laten zien die samen met veel samenwerkingspartners in het veld zijn of worden gedaan. Enthousiaste collega's die er in meer of mindere mate allen toe bijdragen dat ik nu hier sta. Ik heb de afgelopen 15 jaar met veel inspirerende professionals samen gewerkt in vele mooie onderzoeksprojecten. Ik wil al die collega's waarvan er vandaag ook een groot aantal in de zaal aanwezig zijn - enorm bedanken voor deze samenwerking. Al noem ik mensen niet bij naam, ik hoop dat eenieder die het betreft zich gepast aangesproken voelt. Onderzoek doe je immers nooit alleen! Eén onderzoeksteam wil ik speciaal noemen en bedanken omdat we een groot aantal jaren hebben gewerkt aan de chlamydiascreening in Nederland: Jan, Lydia, Eline, Ingrid, Han, Rik, Hannelore, Sander en Elfi. We hebben met zijn allen een indrukwekkende prestatie geleverd en ik kijk er met trots op terug dat ik deel van jullie team mocht zijn.

Goede collega's zijn een zegen. Ik prijs me gelukkig dat ik de laatste jaren bedeeld ben met geweldige collega's met grote betrokkenheid bij de gezondheid van alle burgers. Het feest vanavond is er zeker voor hen. Ik wil de hele afdeling Seksuele Gezondheid, Infectieziekten en Milieu en eveneens de afdeling Medische Microbiologie bedanken voor hun inzet, resultaten, collegialiteit en teamgeest en hun bijdragen aan projecten. Beide afdelingen zijn een thuisbasis voor me. Binnen de afdeling SIM heb ik de ontwikkelingen van dichterbij mee gemaakt en ik heb veel respect voor de positieve ambitie die binnen alle units is ontstaan. Maar ook buiten beide afdelingen zijn er nog veel collega's binnen de GGD Zuid Limburg en het MUMC waar ik nog dagelijks met veel enthousiasme mee samenwerk. Een speciaal woord van dank gaat uit naar Helen als mijn dagelijkse steun en toeverlaat, die mij veel werk uit handen neemt.

Voor hun inzet, creativiteit en doorzettingsvermogen in alle onderzoeksprojecten wil ik een woord van dank richten tot de onderzoekers en promovendi met wie ik direct samen werk. Eerst de seniors: Nicole, dank voor al je 'sparring' en energie in het uitbouwen van onze onderzoeksgroep. Petra, Inge, Frank en Ellen, dank voor jullie gedegen en vruchtbare samenwerking binnen de medische microbiologie. En dan alle onderzoekers: Amanja, Angelique, Anne, Anne-Marie, Carlijn, Elleke, Fleur, Genevieve, Henriëtte, Kevin, Laura, en nog een Laura, Michiel en Volker. Ik sta op jullie schouders. 
Dan zijn er nog mijn dierbare vrienden en familie. Jullie maken uitdagingen in mijn leven van dichtbij mee. Ik dank jullie voor jullie inspiratie, liefde, meeleven, humor en praktische steun. Mam, wat fijn dat je vandaag mee kunt genieten van deze mijlpaal in mijn leven. Jammer dat Jan en Denish dit niet meer mogen meemaken. Jan en Karin, dank voor jullie ondersteuning en Jan voor alle wekelijkse inspirerende wielertochtjes. En Truus, dank voor al je gezinsondersteuning.

En dan mijn gezin waar ik enorm van hou en waar het echt om gaat. Mijn prachtige dochters Aniek en Lisa, dank voor jullie verwondering en enthousiasme in het leven en jullie liefde ...en ook jullie geduld voor mij als ik weer eens achter de computer zit. En dan last but not least: Petra. We hebben samen al veel prachtige avonturen beleefd en ik vind het heel bijzonder om ook deze dag met jou te mogen delen. Jij hebt aan dit hoogtepunt een belangrijke bijdrage geleverd en daarom is deze ook voor jou. Ik dank je voor je onvoorwaardelijke liefde en steun.

Ik dank jullie allen voor de aandacht. Wat fijn dat jullie erbij waren! Ik heb gezegd.

\section{Literatuur referenties:}

1. Geoloog M. de Wit en Microbioloog F. Westall in BBC Earth Story, The living earth, 2010.

2. Grice EA, Segre JA. The skin microbiome. Reviews Microbiology; 9: 244-253.

3. MEJ Woolhouse, Gowtage-Sequeria S. Host range and emerging and reemerging pathogens. Emerging infectious diseases 2005, 11: 1842-5.

4. Morens DM, Folkers GK, Fauci AS. Emerging infections: a perpetual challenge. Lancet Infect Dis. 2008 Nov;8(11):710-9.

5. Jones KE, Patel NG, Levy MA, et al. Global trends in emerging infectious diseases. Nature 2008; 451: 990993.

6. Poon LL, Guan Y, Nicholls JM, Yuen KY, Peiris JS. The aetiology, origins, and diagnosis of severe acute respiratory syndrome. Lancet Infect Dis. 2004; 4(11):663-71. 
7. Hackert VH, van der Hoek W, Dukers-Muijrers N, de Bruin A, Al Dahouk S, Neubauer H, Bruggeman CA, Hoebe CJ. Q Fever: Single-Point Source Outbreak With High Attack Rates and Massive Numbers of Undetected Infections Across an Entire Region. Clin Infect Dis. 2012 Oct 16. [ahead of print]

8. David S (redactie). RIVM rapport: Nationaal soa/hiv-plan 2012-2016 "Bestendigen en versterken", 2011.

9. Waarbeek H ter, Hoebe $\mathrm{C}$, Freund $\mathrm{H}$, Bochat V, Kara-Zaïtri C. Strengthening infectious diseases surveillance in a Dutch-German crossborder area using a real-time information exchange system. Journal Of Business Continuity and Emergency Planning jun 2011; 5(2): 173-84.

10. Ogilvie D, Craig P, Griffin S, Macintyre S, Wareham NJ. A translational framework for public health research. BMC Public Health. 2009 Apr 28;9:116.

11. Bergen JEAM van, Götz HM, Richardus JH, Hoebe CJPA, Broer J, Coenen AJT. Prevalence of urogenital Chlamydia trachomatis increases significantly with level of urbanisation and suggests targeted screening approaches: results from the first national population based study in the Netherlands. Sex Transm Infect 2005;81:17-24.

12. Van den Broek IV, Verheij RA, van Dijk CE, Koedijk FD, van der Sande MA, van Bergen JE Trends in sexually transmitted infections in the Netherlands, combining surveillance data from general practices and sexually transmitted infection centers. BMC Fam Pract 2010; May 20;11:39.

13. Suijkerbuijk AW, van den Broek IV, Brouwer HJ, Vanrolleghem AM, Joosten JH, Verheij RA, van der Sande $M A$, Kretzschmar ME. Usefulness of primary care electronic networks to assess the incidence of chlamydia, diagnosed by general practitioners. BMC Fam Pract. 2011 Jul 8;12:72.

14. Götz HM, Bergen JEAM van, Veldhuijzen IK, Broer J, Hoebe CJPA, Steyerberg EW, Coenen AJJ, Groot F de, Verhooren MJC, Schaik DT van, Richardus JH. A prediction rule for selective screening of Chlamydia trachomatis infection. Sex Transm Infect 2005;81:24-31.

15. Andersen, B; Gundgaard, J; Kretzschmar $M$ et al. Prediction of Costs, Effectiveness, and Disease Control of a Population-Based Program Using Home Sampling for Diagnosis of Urogenital Chlamydia trachomatis Infections. Sexually Transmitted Diseases. 33(7):407-415.

16. Broek van den IVF, Brouwers EEHG, Götz HM, Bergen van JEAM, Fennema JSA, Koekenbier RH, Coul op de ELM, Pars L, Ravesteijn van SM, Hoebe CJPA. Systematic Selection of Screening Participants by Risk Score in Chlamydia Screening Programme is Feasible and Effective. Sex Transm Dis Nov 2012; 88: 205-211

17. Broek van den IV, van Bergen JE, Brouwers EE, Fennema JS, Götz HM, Hoebe CJ, Koekenbier RH, Kretzschmar M, Over EA, Schmid BV, Pars LL, van Ravesteijn SM, van der Sande MA, de Wit GA, Low N, Op de Coul EL. Effectiveness of yearly, register based screening for chlamydia in the Netherlands: controlled trial with randomised stepped wedge implementation. BMJ. 2012 Jul 5;345:e4316.

18. Vries de R, van Bergen JE, de Jong-van den Berg LT, Postma MJ. Value Health. Systematic screening for Chlamydia trachomatis: estimating cost-effectiveness using dynamic modeling and Dutch data. 2006;9(1):1-11.

19. Ford C, Jaccard J, Millstein S, et al. Miller W, Perceived risk of chlamydial and gonococcal infection among sexually experienced young adults in the United States. Perspectives on Sexual and Reproductive Health. $2004 ; 36(6): 258-264$.

20. Richardson D, Maple K, Perry N, Ambler E, Jurd C, Fisher M. A pilot qualitative analysis of the psychosocial factors which drive young people to decline chlamydia testing in the UK: implications for health promotion and screening. Int J STD AIDS. 2010;21(3):187-190.

21. Weinstein ND, Sandman PM. A model of the Precaution Adoption Process: Evidence From Home Radon Testing. Health Psychology. 1992;11(3):170-180.

22. Youm Y, Edward EO. Social Network Effects on the Transmission of Sexually Transmitted Diseases. Sex Transm Dis. 2002: 689-697

23. Potard C, Courtois R, Rusch E. The influence of peers on risky sexual behaviour during adolescence. The European Journal of Contraception and Reproductive Health Care. 2008;13(3):264-270.

24. Samkange-Zeeb FN, Spallek $L$, Zeeb $H$. Awareness and knowledge of sexually transmitted diseases (STDs) among school-going adolescents in Europe: a systematic review of published literature. BMC; 2011:11:727

25. Richardson D, Maple K, Perry N, Ambler E, Jurd C, Fisher M. A pilot qualitative analysis of the psychosocial factors which drive young people to decline chlamydia testing in the UK: implications for health promotion and screening. Int J STD AIDS. 2010;21(3):187-190.

26. Robinson K, Cohen $\mathrm{T}$, Colijn $\mathrm{C}$. The dynamics of sexual contact networks: Effects on disease spread and control. Theor Popul Biol. 2012;81(2):89-96

27. Portnoy DB, Scott-Sheldon LAJ, Johnson BT, et al. Computer-delivered interventions for health promotion and behavioral risk reduction: a meta-analysis of 75 randomized controlled trials 1988-2007. Preventive Medicine. 2008;47:3-16.

28. Doherty IA, Padian NS, Marlow C, et al. Determinants and consequences of sexual networks as they affect the spread of sexually transmitted infections. J Infect Dis. 2005;191(1):S42-54

29. Heckathorn DD. Respondent-Driven Sampling II: Deriving valid population estimates from chain-referral samples of hidden populations". Social Forces. 2002;49:11-34

30. Wejnert C, Heckathorn DD. Web-Based Network Sampling: Efficiency and Efficacy of Respondent-Driven Sampling. Sociological Methods Research. 2008; 37:105-134

31. Salganik MJ. Variance Estimation, Design Effects, and Sample Size Calculations for Respondent-Driven Sampling. Journal of Urban Health: Bulletin of the New York Academy of Medicine. 2006;83(7):i98-i112.

32. Dukers-Muijrers NHTM, Liere van GAFS, Hoebe CJPA. Re-screening Chlamydia trachomatis positives; comparison of practices between STI clinic, general practitioners and gynaecologists. Sexually Transmitted Infections 2012, Sept 2012 as 10.1136/sextrans-2011-050467.

33. Dommelen L van, Tiel FH van, Ouburg S, Brouwers EEHG, Terporten PHW, Savelkoul PHM, Morré SA, Bruggeman CA, Hoebe CJPA. Alarmingly poor performance in Chlamydia trachomatis point of care testing. Sex Transm Infect 2010 Oct;86(5):355-9. 